University of Minnesota Morris Digital Well

University of Minnesota Morris Digital Well

3-26-2015

\title{
Vicente Pagasartundua's Último de los mohicanos: A Racialized Dialogue
}

Thomas Genova

University of Minnesota - Morris, tgenova@morris.umn.edu

Follow this and additional works at: https://digitalcommons.morris.umn.edu/span_facpubs

Part of the Spanish Literature Commons

\section{Recommended Citation}

Copyright 2015 Southeastern Council on Latin American Studies and Wiley Periodicals, Inc.

This Article is brought to you for free and open access by the Faculty and Staff Scholarship at University of Minnesota Morris Digital Well. It has been accepted for inclusion in Spanish Publications by an authorized administrator of University of Minnesota Morris Digital Well. For more information, please contact skulann@morris.umn.edu. 


\section{Vicente Pagasartundua's Último de los mohicanos: A Racialized Dialogue ${ }^{1}$}

This article uses the translation history of North American James Fenimore Cooper’s 1826 Last of the Mohicans to explore the place of race in nineteenth-century republican discourse as it circulated in the Atlantic World. Based not on Cooper's original, but on Auguste Defauconpret’s 1826 French translation, le Dernier des mohicans, Vicente Pagasartundua’s 1832 Último de los mohicanos, like many republican-oriented works in the early nineteenth century, was translated in Spain for a Spanish American audience. Traveling from pre-Jacksonian New York to Orleanist Paris to absolutist Madrid, Cooper's novel and its translations participate in a transnational conversation on the role of racial hierarchies in republican government particularly, as I will show, in regards to the question of the place of Afro-descendants in the republic, a contentious issue in the U.S., France, Spain, and Latin America as the Atlantic World faced events such as the rise of Jacksonian Democracy, the Haitian Revolution, the Cádiz Constitution, and the independence of the Spanish Main.

In the second chapter of his 1845 Facundo, Argentine thinker and statesman Domingo

Faustino Sarmiento claims that the North American Cooper's Last of the Mohicans is filled with “descripciones de usos y costumbres que parecen plagiadas de la pampa.” Bragging of being able to resolve various narrative situations in "Los relatos de Leatherstocking" at least as well as the North American author does, the Argentine concludes by proposing Cooper as a model for NewWorld writers. Marginal though they may seem at first glance, Sarmiento’s comments on Cooper’s foundational Anglo-American novel represent a foundational moment for Latin American fiction, as evidenced by the numerous nineteenth-century works inspired The Last of

\footnotetext{
${ }^{1}$ I would like to thank Sarah Singsank, the UMM Spanish Discipline’s 2013-2014 departmental TA, for her assistance with the research for this paper.
} 
the Mohicans that the region produced, as Argentine Esteban Echeverría’s Cautiva (1837) and Eduarda Mansilla de García’s Lucía Miranda (1860), Brazilaian Jose de Alencar’s Guaraní (1857), Ecuadorian Juan León Mera’s Cumandá (1877), and Uruguayan Juan Zorrilla de San Martín’s Tabaré (1888) demonstrate. Yet, while scholars such as Concha Meléndez, Cynthia Steele, and Doris Sommer have recognized the importance of Cooper's novel to the development of romanticism, indianismo, and foundational romance in nineteenth-century Latin America, little attention has been paid to the ways in which the region's writers of the time might have accessed Cooper's text, --which most of them could not read directly in English —and to the important, racialized differences that exist between the translation and the source text.

Perhaps this silence is due to the traditional disdain that the literary fields have reserved for translation. The only two critical studies that I have been able to find of Spanish translations of Cooper fall victim to this limiting methodological paradigm; Urbano Viñuela Angulo, in his introduction to a contemporary Spanish edition of The Last of the Mohicans, complains of the lack of “calidad y fidelidad al texto original en las distintas traducciones realizadas” while John DeLancey Ferguson, even more disparagingly, writes that "the versions in which [Cooper] was presented to the Spanish public were in most cases the crudest and most mechanical sort of hackwork, turned out at so much per sheet in some Madrileño equivalent of Grub Street” (Ferguson 33). Fortunately, the rise of World Literature as a field, along with Lawrence Venuti's revalorization of translation's place in literary studies and academic works on translation and Latin American literature by Daniel Balderston and Mary C. Schwartz, Suzanne Levine, Earl Fitz and Elizabeth Lowe, and Sarah Pollack, among others, offer scholars the opportunity to reconsider Pagasartundua's translated text, which would play a critical role in the development 
of Latin American literature, particularly in regards to its function as a vehicle for racial republican ideas in the nineteenth century. ${ }^{2}$

As North American readers know, written towards the end of the transatlantic Age of Revolution, Cooper's racially and class-inflected novel -- in which the half-Scottish, halfJamaican Cora Munro is desired by white and indigenous men before ultimately perishing--, registers the author's uneasy stance towards the transition between early Republican society and the continental empire model of the Jacksonian United States, a model in which race --not class-organizes social hierarchies. Published just three years before Andrew Jackson would assume the presidency, The Last of the Mohicans "search[es] for answers to the greatest questions posed by the unrealized promise of this new nation: 'Who shall inherit the American land?' 'What form of society shall we establish?’ and, above all, ‘What is the meaning of political justice in a republic?’” (McWilliams 11).

Curiously, though twentieth-century Anglo-American scholars from D.H. Lawrence to Leslie Fielder to Doris Sommer have tended to cast Cooper as a reactionary for the racial exclusivity of his novels, nineteenth-century Europeans seem to have read the North American writer as a liberal reformer. A June 19, 1827 review in le Globe recommends the work to "notre jeunesse intelligente qui semble disposée á élever á la science un trône ou un sanctuaire sur les ruines de la liberté, qui regarde comme déjá suranuées les simples et glorieuses doctrines qui

\footnotetext{
${ }^{2}$ The Last of the Mohicans was translated twice into Spanish during the early nineteenth century. In addition to Pagasartundua's Madrid translation, there exists another 1832 version published in Valencia and signed by "J.M.P." called El último mohicano. In this article, I have chosen to focus on Pagasartundua's translation, which I believe to have been the more influential of the two. For example, Pagasartundua's text seems to have been the Spanishlanguage edition of the novel that Sarmiento read before penning his remarks on Cooper. While the Argentine would have been able to read Cooper's novel in French translation, he always refers to the work by Pagasartundua's title, El último de los mohicanos (instead of J.M.P.'s El último mohicano or Defauconpret's le Dernier des mohicans), indicating that that is the edition he probably read. (Sarmiento tends to quote English-language works in French when he knows them through their editions in that language, as is the case of the citations from Shakespeare that appear in Facundo). For a list of Spanish translations of Cooper’s works, see Urbano Viñuela Angulo, "James Fenimore Cooper: Entre la popularidade [sic] y la transformación textual.”
} 
l’Amérique avait appliquées avant que la France les proclamâ en 1789” [“our intelligent youth, who seem disposed to raise to science a throne or sanctuary upon the ruins of liberty, who view as already outmoded the simple and glorious doctrines that America had applied before France proclaimed them in 1789"] (174). Commenting on the review, critic Martin Green claims that "the [European] response to Cooper is part of a response to America" (148-9) and that the author was often seen as "the emblem of everything which Europe and the Bourbons had denied" (Green 148). Similarly, in his 1916 American Literature in Spain -which, though somewhat jingoistic, remains the most extensive survey of the reception of North American literature in the nineteenth-century Iberian context—Ferguson argues that "the United States was regarded by oppressed and hunted Spanish Liberals as the embodiment of human freedom and all that is best and noblest in government” (Ferguson 3) and that, in general, North American literature was read by nineteenth-century Spaniards as an expression of liberal values.

In this context, Pagasartundua's version of Defauconpret's French translation of The Last of the Mohicans fits into the cultural paradigm, common at that time, of Spaniards translating republican thought from France into Spanish for a Latin American audience, partially as part of a post-Cádiz ${ }^{3}$ tendency among Spanish liberals towards transatlantic rapprochement and partially in an effort to circumvent the censorship of Ferndando VII's absolutist Spain (Llorens 156). The New-World context clearly played a role in the work’s Iberian reception. A July 12, 1832 review of Pagasartundua's translation in Cartas españolas, for example, praises Cooper's presentation of “escenas de la naturaleza salvage modificada á veces y otras combatida por las invasiones no interrumpidas de la civilizacion en aquellos paises" (61) because "causa un placer voluptuoso de

\footnotetext{
${ }^{3}$ In 1810, in response to the Napoleonic invasion of Spain, delegates from across the Empire convened in the unoccupied Andalusian city of Cádiz. Their 1812 Constitution famously abolished the colonial status of the oversees provinces and granted citizenship to all inhabitants of Spanish lands with the exception of those "habidos y reputados por originarios del África (Art. 22).” For more on race in the Constitucion de Cádiz, see Lasso.
} 
noble sensibilidad, el ver á un cazador que abandonando las comodidades de la civilizacion se hace hijo adoptivo de las selvas, haciéndose el amigo y el confidente de los indios, al propio tiempo que arriesga mil veces tranquilamente su vida por favorecer todos los individuos de la civilizacion" (61). ${ }^{4}$ Continuing in this Euro-centric tone, the reviewer concludes that "aparte del interes general que hay en toda la novela interesa tanto mas por el fin lastimoso de una muger interesante, Cora, y el de un jóven salvage, último vástago de una familia gefe de los Mohicanos" (61). Freely using terms such as "indio" and the nineteenth-century racial code words "civilización” and "salvaje," the review indicates that Pagasartundua’s translation was received and read within a racial framework. It is curious, then, that, while the reviewer has no qualms about referring to Cooper’s Uncas as “un joven salvaje,” the character of Cora, who is half-Scottish and half-Afro Jamaican, is mentioned without reference to her ancestry. The silence surrounding Cora's mixed-race identity in Spanish reviews is particularly striking when one considers how central the character's blackness was to the North American reception of the novel. An unsigned reviewer in the March 1826 edition of the New-York Review and Atheneum, for example, fumbles the question of Cora’s blackness for close to a page:

\begin{abstract}
We are introduced at the commencement to two delightful females, daughters of one sire, though by different mothers [...] In the veins of the former ran a mixture of Creole blood; or, in other words, one of her female ancestors, in the Occidental Indies, was of African extraction. This sufficiently accounts for her differing in complexion and character from her fair-haired and bright-eyed sister, the daughter of a Scottish mother; but what capital points the author meant to make out of this distinction, we confess ourselves obtuse enough not to have discovered. Cora, the eldest sister, is sometimes made to assume all her dignity, when a casual observation suggested the recollection of her descent; but the effect is unpleasant, and in no wise poetical. Munro, the father, when he learns from Duncan Heyward [...] that he is a suitor for Alice, the younger sister, gives vent to a transient paroxysm of indignation, as if he suspected that the young soldier, born in southern latitudes, slighted his elder daughter on account of the sable tinge in her escutcheon. But Duncan was certainly at liberty to make his election, independent of any such peculiarity. Cora had likewise a secret partiality for Duncan, which her maiden pride and delicacy properly controlled; but we cannot discern how the purposes of the fiction can be helped, by the supposition that his preference of her younger sister was in anywise to be ascribed to his prejudice of education against the descendants of
\end{abstract}

\footnotetext{
${ }^{4}$ The quote conforms to the prevalent orthographic conventions of the time. I have retained the original spellings in the nineteenth-century quotations used throughout this article.
} 
negroes. It was natural, too, for Uncas to be more attracted by the fuller proportions and brilliant colour of the noble girl, who was ready, at any moment, to sacrifice herself for the more fragile Alice; but this does not render a frequent, inartificial, and painful allusion to an hereditary taint at all necessary” (92-93).

Lost in awkward elaborations, the reviewer fails to conceal his true feelings: unable to decipher the narrative necessity of Cora's African descent, he cannot conceive that Cooper may have cast a mixed-race woman in the role of heroine. For this critic, Cora's blackness represents a problem that he cannot, despite his protracted efforts, explain away.

W.H. Gardiner's words in the July 1826 edition of the North American Review are more direct, if no less virulent, in their condescension:

The respective characters of these young ladies are as opposite as their complexions. Alice is timid and sensitive, always shrinking and shrieking at the approach of danger; while Cora is quite a bold young woman, and makes rather free, we think, with the savages. This, probably, she felt the better title to do, in respect of the dark blood which flowed in her own veins” (Gardiner 110).

Gardiner goes on to complain that:

In the present case, we are free to confess, that so far as Cora is concerned, our judgments [...] may be somewhat biassed [sic]. We mean no offence whatever to the colored population of the United States; on the contrary, we have a great esteem for them in certain situations; and we acknowledge it to be a vile and abominable prejudice; but still we have (and we cannot help it) a particular dislike to the richness of the negro blood in a heroine (Gardiner 111).

Given the recurrence of critiques regarding Cora's racial identity in US reviews of Cooper's novel, why should Spanish reviews of the translation fail to comment on the topic? One can hardly claim that the foreign critics were less prejudiced than their North American counterparts; the very same Spanish and Latin American liberals for whom the translation of the republican novel was marketed had, after all, in the 1812 Cádiz Constitution, barred Afro-descendants from citizenship. 
As it turns out, Cora’s blackness may have been difficult for Spanish-speaking audiences to notice. While the character's secret identity is revealed in the translated texts in the same abrupt manner as it is in the original (Cooper 171; Pagasartundua I: 322, following Defauconpret II: 114$),{ }^{5}$ her features are lightened throughout the novel. In his initial description of the heroine, Cooper writes that "her complexion was not brown, but it rather appeared charged with the color of rich blood, that seemed ready to burst its bounds” (17), which, while not declaring Cora nonwhite, informs the reader that, in a very un-Anglo Saxon fashion, the character's blood is not under control. In his French translation, Defauconpret strikes Cooper’s reference to blood and renders the sentence as "son teint n’etoit pas brun, mais très coloré” ["her complexion was not brown, but very colored”] (22). Pagasartundua, in turn, translates Defauconpret’s words as “su tez no era morena sino encarnada” (31). Disavowing Cora’s blackness by stating that her skin is not “morena” (the racialized term), but “encarnada,” Pagasartundua deracializes the character

\footnotetext{
${ }^{5}$ Curiously, in this passage, while the translated texts acknowledge Cora's blackness, they assimilate the character's racial origins to the republican rhetoric of the era. Cooper writes that Cora's mother was descended from "that unfortunate class who are so basely enslaved to administer to the wants of a luxurious people" (171). Departing somewhat from his North American source text, Defauconpret renders the sentence as "cette classe infortunée qu'on a la barbarie de réduire á un infâme esclavage pour fournir aux besoins du luxe des nations civilisées” (114), which becomes "esta clase desgraciada que se tiene la barbarie de reducir á la esclavitud para proveer á las necesidades del lujo de las naciones civilizadas” in Pagasartundua’s Spanish (322). Though the spirit of the French and Spanish versions are the same as that of the English, Defauconpret (and Pagasartundua - perhaps unwittingly—after him) grafts the discourse of civilization and barbarism that would play such an important role in the European (and, after Sarmiento, Latin American) lettered sphere during the nineteenth century onto Cooper's text. Here, however, the translators have erased the binary; it is not that the Europeans are civilized and the Africans are barbarous; rather, the "civilized nations" of Europe "have the barbarism" to "reduce" Africans to slavery.

In this scene in Cooper's novel, Cora's father goes on to compare his own Scottish ancestors to Africans, noting that both have been "enslaved" as a result of Scotland's "unnatural union with a foreign and trading people” (171). Once again translating literally from Defauconpret, Pagasartundua renders the expression as "su union contra naturaleza, á una tierra estrangera y á un pais de traficantes” (322). In the Hispanic context, this unnatural union recalls the relationship between Spain and the Americas, much as, in Cooper's English, the reference to Scotland brings to mind the situation of the newly independent United States under British rule. The allusion is stronger in Spanish, however, because Pagasartundua's "union contra naturaleza” echoes Simón Bolívar’s metaphorical representation of Spain as a "madre desnaturalizada" in his 1815 "Carta de Jamaica." Moreover, while Cooper's reference to the English as a "trading people" reflects the author's aristocratic disdain for bourgeois entrepreneurialism, the more accurate Spanish term would have been "pueblo de comerciantes" -not "traficantes." The term "traficante" suggests illicit commercial activity, such as "el tráfico de esclavos" -precisely the metaphor that Cuban liberals would use to describe Spanish colonialists as the nineteenth century progressed (see Luis and Williams). Much as, in physical descriptions of the character, Cora's dark complexion is displaced from her noticeable skin and hair to her less obvious eyes, here, her blackness is subsumed and subordinated by liberal discourse rather than allowed to stand as a self-justifying subject.
} 
even further than does Defauconpret, switching the French translator's "colored," which might allude to blackness (as in the French colonial category of "gens de couleur libres"), with “encarnada,” that is, "flesh-colored,” or "reddish.” Gone is Cooper’s allusion to untamed blood of mysterious provenance, replaced by an image of Cora as flushed and ruddy. Similarly, while Cooper consistently refers to Cora as “dark-haired” (106, 109, etc.), Pagasartundua follows Defauconpret’s lead away from the North American author's words, and translates the Frenchman’s “fille aux yeux noirs” (I 13-14 and II:5) as “la jóven de los ojos negros” (I:201 and 207-8). As eyes are less visually striking than hair, the shift in focus lessens the racialized phenotypical difference that Cooper seeks to suggest in his repeated references to Cora's appearance. So successful is the translators' lightening strategy in drawing attention away from Cora's blackness that F.A.S.'s July 2, 1827 continuation of his June 19 review in le Globe refers to her as "la jeune fille blanche aux yeux noirs” [“the young white girl with black eyes”]. (Once again, the Spanish reviewers that I have consulted do not comment on her race at all.)

More subtly, Defauconpret and Pagasartundua's translations do not stop at lightening Cora's physical appearance, but extend their whitening efforts to the figurative language describing her person. When potential suitor Duncan Heyward attempts to express his greater love for Cora's white half-sister, Alice, than for Cora, Cooper writes that the mixed-race heroine’s "worth was in a degree obscured" by the character's romantic feelings for her sister, obliquely suggesting that Cora's darkness (obscurity) makes her an unworthy marriage partner a pun that, given the word's similarity to the French obscurité and the Spanish oscuridad, Defauconpret and Pagasartundua could not have failed to notice. Both translators, however, replace the idea of obscured worth with a reference to the suitor's "preference" for Alice 
[“préférence” (Defauconpret III:217) and "preferencia” (Pagasartundua II: 178)], in this way eliminating Cooper's racist double entendre.

Even more curiously, Cora is not the only nonwhite character that Defauconpret and Pagasartundua discursively whiten. The translators also remove mentions of darkness when they refer to Amerindians. Thus, where Cooper says of one indigenous character that "the colors of the war-paint had blended in dark confusion about his fierce countenance, and rendered his swarthy lineaments still more savage and repulsive” (15), Pagasartundua, translating Defauconpret, writes "los colores de que los salvages componen la pintura de sus cuerpos cuando se preparan á pelear, se habían fundido y mezclado en su fisionomía que anunciaba la fiereza, y la daban un carácter todavía más repugnante” (30-31), omitting the today-offensive reference to the "swarthiness" of the Amerindian. Importantly, in this passage, not only is darkness removed as a phenotypical characteristic of the Amerindian, but it disappears from the paint on his body, as well. If Cooper speaks of the "dark confusion" into which the colors of the war paint had blended, the translation says that the colors "se habían fundido y mezclado" with no reference to their tone. Similar examples abound throughout Pagasartundua's text, most of which have their origin in Defauconpret. For example, when Cooper writes, "the swarthy countenance of the attentive Indian” (106); Pagasartundua simply translates "el semblante del indio” (I: 201). On another occasion, when Cooper states that the Amerindians' "dark persons were still to be seen within the shadows of the block house" (134), Pagasartundua limits himself to "apenas se los distinguia en la oscuridad" (I: 252). Here, the dark bodies are not translated, but the shadows are. Darkness in the quote becomes a property of the Amerindians' surroundings -not their persons. 
In Cooper's text, the constant casting of Amerindians in shades of darkness has the effect of placing blackness and indigeneity on the same plane, discursively transforming one into a function of the other. On the narrative level, the imbrication between the two racial categories is reflected in the romantic desire that the half-Scottish, half-Jamaican Cora inspires in both Uncas and Magua, the two most important Amerindian characters in the novel. Importantly, the three manage to die on the same page and Cora and Uncas are buried together, indicating an intertwined history and shared future of banishment from the republican community that Cooper imagines. In this way, the recent memory of the First Seminole War, in which the Monroe administration fought a mixed Afro-indigenous group on the nation's Southern border, is mirrored by Cooper's novel about the Munro family and the Afro-indigenous alliance on the Northern border.

At least one contemporary reader understood the novel's ending through this interracial paradigm. Commenting on the improbable deaths of Uncas and Cora, an unsigned reviewer in the May 1826 issue of The United States Literary Gazette writes that "Uncas would have made a good match for Cora, particularly as she had a little of the blood of a darker race in her veins.” In a timely allusion to the First Seminole War, he adds that "this sort of arrangement is coming into fashion, in real life, as well as in fiction” (100). In encouraging an interracial marriage plot, however, the apparently progressive reviewer misses Cooper’s point. The Last of the Mohicans hints at Uncas's feeling for Cora not to extoll Afro-indigenous alliance, but to disavow it. In their deaths, Uncas and Cora, like the Black Seminoles after the War, are expelled from the republic's borders so that whites may found the nation.

Yet, if Cooper discursively blackens his Amerindian characters in order to refuse the possibility of the alliance that his very language suggests, Defauconpret and Pagasartundua do 
not hazard even that. While Defauconpret's biographer in the Biographie universelle ancienne et modèrne praises the translator for polishing Cooper's notoriously verbose English into elegant French prose (269), it is difficult to view his omissions of the references to darkness from his descriptions of Amerindians as a mere cutting through dead wood because of the consistency with which he chooses not to translate these adjectives, even when they would do little to weigh down his sentences. We may never be able to ascertain Defauconpret’s motives with certainty, though a French public that had recently lost to Afro-New World troops calling themselves the "armée indigène” in Haiti may have preferred to keep the categories of black and indigenous (and, with them, the memory of their own legacy of semi-feudal despotism) separate as they entertained Cooper's republican notions. ${ }^{6}$ Similarly, regardless of whether or not Pagasartundua was aware of Defauconpret's modifications to Cooper's text, one cannot help but imagine that the original, in which blacks and Amerindians were discursively equated with one another, would not have been well received in a Hispanic world that had recently denied citizenship to Afro-descendants on the grounds that their ancestors were not natives of the Empire, as were those of whites, mestizos, and the indigenous.

Yet, ultimately, New-World slavery could not be kept out of Hispanic receptions of The Last of the Mohicans, no matter how subtly the topic was broached. Rafael María de Labra's 1879 discussion of the novel in a Revista de España article on Cooper, Harriet Beecher Stowe, and Edgar Allen Poe is a case in point. While, oddly enough, Labra --who, born in Havana, was president of the Spanish Abolitionist Society and a longtime defender of colonial rights—does not mention the peculiar institution in conjunction with Cooper, his discussion of the novelist is preceded by a history of the United States, including a lengthy treatment of the initial introduction of slaves into the Virginia colony. This event, he feels, was "llamada á producir

\footnotetext{
${ }^{6}$ For more on indigenism in Haitian revolutionary discourse, see Fischer 236-244.
} 
inmensos conflictos y una crísis aterradora en la naciente república” (461). Similarly, the discussion of Cooper is followed by a treatment of Harriet Beecher Stowe in which Labra, after mentioning Haiti in passing (475), claims that slavery is "el mayor peligro para la consolidación de [la República]” (476). Labra then proceeds to refer to Poe as a Southerner multiple times before pronouncing the writer the poetic embodiment of the North American entrepreneurial spirit (488). Taking some liberties with US literary and political history, the path that the abolitionist Labra maps out in his article suggests that New-World plantation societies -such as Jamaica or Cuba, the sites of Cooper's Cora and Rafael Labra's respective births--, if they follow the teleology from neocolonialist Cooper to abolitionist Stowe that the statesman has laid out, are capable of greatness.

In the concluding paragraph, Labra attempts to vindicate the U.S. from European disdain and points to "las mudanzas y transformaciones de la vida política, que demuestran las Emiendas constitucionales de 1791 á 1870, y la última trascendental guerra civil; y en fin, qué papel desempeñan los Estados Unidos de América, como factor importantísimo en la cultura intelectual del siglo corriente” (Labra 489). This list ties the growth and success of North American republicanism to the rise and triumph of antislavery, as the references to the Civil War and the $15^{\text {th }}$ Amendment of 1870 , which prohibited the denial of the right to vote based on race, color, or previous condition of servitude, make clear. Importantly, in addition to the final ratification of the Bill of Rights, 1791 marks another important date in New World republican history: the start of the Haitian Revolution, the event that may very well have driven Defauconpret to excise much of the racial language from Cooper's novel and which inspired a major slave rebellion in Labra’s native Cuba in the same year in which the Cortes de Cádiz 
passed their racially exclusive Constitution. ${ }^{7}$ In his article, then, the abolitionist and anticolonialist Labra subtly inserts Cooper’s work into the very context of Afro-New World liberation from which translators Defauconpret and Pagasartundua -and even Cooper himselfhad tried so desperately to extricate the text.

The translational history that I have mapped here points to a transnational conversation on race and republicanism, complicating the commonplace narrative of early New-World political philosophy as a mere imitation of European models. While Latin Americanists typically hold that republican thought travelled unidirectionally from France to the Americas, the travels of The Last of the Mohicans are an example of a republican text flowing in the opposite direction. Moving from New York to Paris to Madrid and losing much of its colonial particularity along the way, the text was taken up in Spain by a Cuban-born diputado and reshaped into an anticolonial discourse. Such a trajectory, in which Europe is a receptor and transculturator of New-World ideas that would later be reappropriated back into the Western Hemisphere, begs a reconsideration of the long-held scholarly belief in the Euro-centric nature of nineteenth-century Latin American republican thought.

\section{Bibliography}

Alencar, José de. O guarany. 1857. Rio de Janeiro: Antundes, n.d. Print.

Balderston, Daniel and Marcy C. Schwartz. Voice Overs: Translation and Latin American Fiction. Albany: SUNY Press, 2002. Print.

Cooper, James Fenimore. The Last of the Mohicans. 1826. New York: Heritage, 1932. Print.

Cortes de Cádiz. La Constitución española de 1812. 1812. Biblioteca Virtual Miguel de Cervantes. Web. 9/14/10.

Defauconpret Auguste-Jean-Baptiste. Biographie universelle, ancienne et moderne. Paris:

\footnotetext{
${ }^{7}$ On the 1812 Aponte Conspiracy in Cuba, see Franco and Palmié.
} 
Thousnier Desplaces, 1852. 269. Web. 4/9/14.

Defauconpret, Auguste Jean-Baptiste. Le dernier des mohicans. Histoire de 1757 (4 vols.). Paris: Charles Gosselin, 1826. Google Books. Web. 3/15/14.

Dekker, George and John P. McWilliams, eds. Fenimore Cooper: The Critical Heritage. London: Routledge \& Kegan Paul, 1973. Print.

Echeverría, Esteban. "La cautiva.” Obras completas de D. Esteban Echeverría. Tomo Primero. Buenos Aires: Imprenta y Librería de Mayo, 1870. 35-138. Biblioteca Virtual Miguel de Cervantes. Web. 7/1/11.

El último de los mohicanos. Cartas españolas. 6 (July 12, 1832): 61-62. Hermeroteca Digital. Biblioteca Nacional de España. Web. 4/9/14.

F.A.S. “États-Unis. Littérature americaine. Romans de M.Cooper.” le Globe: Recueil philosophique et littéraire. V.33 (June 19, 1827): 205-207. Print.

“États-Unis. Littérature americaine. Romans de M.Cooper.” le Globe: Recueil philosophique et littéraire. V.39 (July 2, 1827). 205-207. Print.

Ferguson, John De Lancey. American Literature in Spain. New York: Columbia UP, 1916. Googlebooks. Web. 4/9/14.

Fischer, Sybille. Modernity Disavowed: Haiti and the Cultures of Slavery in the Age of Revolution. Durham: Duke UP, 2004. Print.

Fielder, Leslie A. Love and Death in the American Novel. New York: Criterion Books, 1960. Print.

Franco, José Luciano. “La conspiración de Aponte, 1812.” Ensayos históricos. Ciencias Sociales: Havana, 1974. 125-190.

Gardiner, W.H. Untitled Review. North American Review. 1826. Dekker and McWilliams. 104118. Print.

Green, Martin. Dreams of Adventure, Deeds of Empire. New York: Basic Books, 1979. Print.

J.M.P. El último mohicano. Historia americana escrita en ingles por J. Fenimore Cooper. Imprenta José de Ogra: Valencia, 1832. Googlebooks. Web. 4/9/14.

Labra, Rafael María de. "La literatura norteamericana en Europa: J.Fenimore Cooper - Harriet Beecher Stowe - Edgar A. Poe. Revista de España. 67 (April 1879): 457-489. Hemeroteca Digital. Biblioteca Nacional de España. Web. 4/9/14.

Lasso, Marixa. Myths of Harmony: Race and Republicanism in the Age of Revolution, 
Colombia, 1795-1831. Pittsburg: U Pittsburg Press, 2007. Print.

Lawrence, D.H. Studies in Classic American Literature. New York: Doubleday, 1922. Print.

León Mera, Juan. Cumandá, o, un drama entre salvajes. Ed. Ángel Esteban. Madrid: Cátedra, 1998. Print.

Levine, Suzanne Jill. The Subversive Scribe: Translating Latin American Literature.

St. Paul: Greywolf, 1991. Print.

Lowe, Elizabeth and Earl Fitz. Translation and the Rise of Inter-American Literature. Gainesville: UP of Florida, 2007. Print.

Luis, William. Literary Bondage: Slavery in Cuban Narrative. Austin: U of Texas Press, 1990.

Llorens, Vicente. Liberales y románticos: una emigración española en Inglaterra (1823-1834). Madrid: Castalia, 1968. Print.

Palmié, Stephan. Wizards and Scientists: Explorations in Afro-Cuban Modernity and Tradition. Chapel Hill: Duke UP, 2002.

Mansilla de García, Eduarda. Lucía Miranda. 1860. Biblioteca Virtual Universal. 2003. Web. 1/7/11.

Meléndez, Concha. La novela indianista en Hispanoamérica (1832-1889). 1934. Obras completas. San Juan: Instituto de Cultura Puertorriqueña, 1970. Print.

McWilliams, John P, Jr. Political Justice in a Republic: James Fenimore Cooper's America. Berkeley: UCP, 1972. Print.

Pagasartundua, Vicente. El último de los mohicanos. Historia de mil setecientos cincuenta y siete (2 vols.). Madrid: Tomás Jordán, 1832. Google Books. Web. 3/15/14.

Pollack, Sarah. "After Bolaño: Rethinking the Politics of Latin American Literature in Translation.” PMLA 128.3 (May 2013): 660-667. Print.

Sarmiento, Domingo Faustino. Facundo: Civilización y barbarie. 1845. Ed. Noé Jitrik, ed. Barcelona: Ayacucho, 1995. Print.

Sommer, Doris. Foundational Fictions: The National Romances of Latin America. Berkley: UCP, 1991. Print.

Steele, Cynthia. Narrativa indigenista en los Estados Unidos y México. Mexico: Instituto Nacional Indigenista, 1985.

Unsigned Review. 1826. United States Literary Gazette. Dekker and McWilliams. 97-103. Print. 
Viñuela Angulo, Urbano. Introduction. El último mohicano. Madrid: Cátedra, 1997. James Fenimore Cooper Society. oneta.edu. Web. 4/9/14.

“James Fenimore Cooper: entre la popularidade y la transformación textual” [sic]. Livius (Journal of Translation Studies): 4 (April 1993). James Fenimore Cooper Society. oneta.edu. Web. 4/9/14.

Venuti, Lawrence. The Translator's Invisibility: A History of Translation. London: Routledge, 1995. Print.

Williams, Lorna Valerie. The Representation of Slavery in Cuban Fiction. Columbia: U of Missouri Press, 1994.

Zorrilla de San Martín, Juan. Tabaré. 1886. Mexico City: Porúa, 1970. Print. 